\title{
Strengthening National Logistic Ecosystem to Increase Indonesia Competitiveness in International Trade
}

\author{
Elfi Haris ${ }^{1}$, OK. Saidin ${ }^{2}$, Ningrum Natasya Sirait ${ }^{3}$, Maria Kaban ${ }^{4}$ \\ ${ }^{1,2,3,4}$ Universitas Sumatera Utara \\ Email: elfi.hariss@gmail.com, saidin@usu.ac.id, ningrum@usu.ac.id, mariakabans@yahoo.com
}

\begin{abstract}
One aspect that determines the competitiveness of a country is the arrangement of national logistics. Logistics is a supply chain of goods and services from the producer to the goods received by the final consumer. The value of an item is determined by various factors such as production costs, marketing costs, logistics and expected profits. Business practitioners say that the price of an item contains at least $24 \%$ of the logistics cost factor. This research is to see the condition of Indonesia's national logistics and the efforts that can be made in managing the national logistics. The research method is normative legal research with primary and secondary data sources. One of the considerations of investors who will invest in a country is the logistics performance of that country. A reliable source of data and usually used as a reference is a survey conducted by the World Bank in the form of the Logistics Performance Index. In 2018 Indonesia was still ranked 46th with a score of 3.15. Indonesia's position is under Singapore, Thailand, Vietnam and Malaysia. This condition is in accordance with the fact that the value of investment entering Indonesia is still below the neighboring countries, especially Vietnam. This shows that there are problems in Indonesia's logistics that need to be strengtheningd. The number of parties involved in the display of goods from the port, the same notification must be made repeatedly in the process of releasing goods, inadequate infrastructure and high congestion add to the problems in Indonesia's logistics performance. The government must strengthening to strengthening Indonesia's competitiveness in international trade. With national logistics, it is hoped that the efficiency of Indonesian manufactured goods will be created which will ultimately be able to compete with the products of other countries.
\end{abstract}

Keywords: Logistics, ports, competitiveness, IPL

\section{INTRODUCTION}

The price of a good does not merely depend on the cost of producing the good, but also on costs related to logistic, promotion, and revenue margin. Business practitioners mention that logistic cost comprises at least $24 \%$ of a good price. Anthon Sihombing, the General Chief of Indonesia Importers Association mentions that logistic cost in Indonesia is considerably high compared to neighboring countries. He mentions that in fact, Indonesia logistic cost ranges up to $25-30 \%$ of a good price. ${ }^{[1]}$

It means that of Rp100.000 price of a good, the logistic cost contained in the price is $\mathrm{Rp} 25.000$. These statements are shocking, but facts confirm them. For example, a cloth produced in Indonesia is more expensive than those produced in China, Vietnam, or other countries. If only the logistic cost can be reduced to $50 \%$, the good's price can decrease to Rp 87.500.

Several logistic literatures explain supply chain as well. Russel and Taylor define supply chain as a process that encompasses all activities related to a the flow and transformation of a good or service from the raw material stage to the end user (customer), as well as information flow. Supply chain integrates process groups to obtain, produce, and send products. ${ }^{[2]}$

The definition put forward by Russel an Taylor is extensive, starting from efforts in obtaining raw material, producing process, to the process of sending/delivering good or product to end consumer. If this supply chain takes place in international trade, it will involve some countries with different legal regulations.

The management of Indonesia supply chain is mapped in a program known as National Logistic Ecosystem (NLE). NLE is a logistic ecosystem that aligns the traffic flow of international goods and documents since the coming of transport means to the arrival of goods in storehouse. ${ }^{[3]}$ Although the NLE team in essence understands that the concept of logistic starts from good process in producer's storehouse to the arrival of good in consumer's storehouse, considering the extent of logistic and the involvement of other countries, the national logistic ecosystem management conducted will be limited to the coming of transportation means in 
Indonesia custom territory to the arrival of goods in customer storehouse.

The President in some chances has directly brought forward the condition of Indonesia logistic. In the limited meeting on Wednesday, 18 March 2020, the President expressed that Indonesia logistic ecosystem is not efficient yet in terms of time as well as cost, has many complicated processes in bureaucracy side, many repetitions, many duplications, and strong sectorial siloes of ministries moving on their respective ways.

The Finance Minister in some chances expresses that Indonesia logistic cost comprises $23,5 \%$ of Gross Domestic Product (GDP). The rate is considerably high compared to neighboring countries such as Malaysia that has only $13 \%$. This statistic becomes a reference for investors that investment in Malaysia is $10 \%$ more efficient than investment in Indonesia. This condition hampers the growth of investment in Indonesia. Although investment promotion is conducted massively and programmed, the impact will not be as maximum as intended if it is not followed by efforts of improving national logistic.

Other indicator normally used internationally to capture logistic performance of a country is Logistics Performance Index (LPI). LPI is an interactive indicator designed to assist countries in identifying challenges and opportunities facing them in trade logistic and what they can do to strengthening their performance. ${ }^{[4]}$ Elements measured in LPI are:

1. Efficiency in customs clearance and border management.

2. The quality of infrastructure of trade and transportation.

3. Ease of regulation and competition of international shipment.

4. Logistic service competence and quality.

5. Ability to trace and track shipment.

6. The frequency of consignee receiving goods in the scheduled or expected shipment time.

In 2018, Indonesia LPI was on $46^{\text {th }}$ rank with 3,15 score. Statistically, Indonesia's LPI rank and score in 2018 strengtheningd from 2016. In 2016 Indonesia was on $63^{\text {rd }}$ rank with 2,98 score. The LPI strengtheningment does not necessarily strengthening the competitiveness or Indonesia logistic performance. With the score and rank, Indonesia is outperformed by Singapore, Thailand, Vietnam, and Malaysia.

Table 1. ASEAN Countries LPI Comparison 2018

\begin{tabular}{|l|l|c|c|}
\hline NO & COUNTRY & SCORE & RANK \\
\hline 1 & Singapore & 4,00 & 7 \\
\hline 2 & Thailand & 3,41 & 32 \\
\hline 3 & Vietnam & 3,27 & 39 \\
\hline 4 & Malaysia & 3,20 & 41 \\
\hline
\end{tabular}

\begin{tabular}{|l|l|c|c|}
\hline 5 & Indonesia & 3,15 & 46 \\
\hline
\end{tabular}

Indonesia needs to undertake national logistic reform immediately. The first step is formulating law arrangement that is in line with the current business condition based on the sublime values of Pancasila and UUD 1945. Considering the rapid change in society behavior due to the effect of environmental change caused by rapid development, it is urgent to formulate an up to date law arrangement. In other words, law should not fall behind the strengtheningment process in society. Sustainable development requires law concept that is able to stimulate and direct development as the reflection of modern law goals. ${ }^{[5]}$

\section{PROBLEM}

1. What is the current condition of Indonesia national logistic?

2. What is main priority in national logistic program in order to enhance the competitiveness if Indonesia's products?

\section{NATIONAL LOGISTICS AND INDONESIA'S COMPETITIVENESS}

\subsection{National Logistic Arrangement That Influences Indonesia's Competitiveness}

International trade is inevitable for a country. Given the surplus and shortage of production factors in each country, international trade is a way to resource efficiency. Nonetheless, the production factor surplus alone does not guarantee that a good value is lower and competitiveness is high.

Many other factors influence the competitiveness of a country such as the movement of goods from a country to other country, goods handling in port, storing cost, tax and import duties. Indonesia competitiveness referred to in this research is Indonesia's ability to gain, produce, and/or sell goods and/or services at the same price as those gained, produced, or sold in other countries.

The value of a good consists of several components such as raw material prices, labor salary, promotion cost, producer's revenue, seller's revenue, and logistic cost. National logistic is a series of activities that starts from the arrival of ship to Indonesia's custom area to the arrival of goods to consumer's storehouse. The serious attention of government to the effective and efficient development of logistic system is expressed on the National Logistic System Blue Print (Cetak Biru Sistem Logistik Nasional - Sislognas) 2012 and Economic Policy Package XV 2017. This logistic system is expected to be able to enhance local competitiveness at global level so the strengtheningment of society's prosperity will be realized.

Logistic activities in every country have similarities yet are different in every process, depending on society's 
culture, regulation, and technology. A detailed and thorough understanding on every logistic process needs to be obtained by stakeholders, so that the developed logistic system can be realized in accordance of the existing uniqueness. ${ }^{[6]}$ In international language, the term logistic is also mentioned as supply chain. Lang Li states that supply chain management is a series of intertwined activities and decisions that integrate suppliers, manufacturers, storehouse, transportation service, retailer and consumer efficiently. ${ }^{[7]}$ Supply chain is all integrated activities including information related to three aspects viz. source, production process and product delivery process. There are three components in supply chain:

1) upstream supply chain that includes various activities of company with supplier, among others raw material and subsidiary material procurement.
2) Internal supply chain that includes all inflowing processes to storehouse up to the production process. The main activities are among others production and inventory control.

3) Downstream supply chain that includes all activities that involve product shipment to customer. The main focuses of the activity are distribution, storing, transportation, and service.

In managing Indonesia national logistic, activity process starts from the arrival of transportation means in the form of ship and/or aircraft and/or land transportation mean to Indonesia's customs territory to the arrival of good to customer's place. The logistic flow is illustrated below.

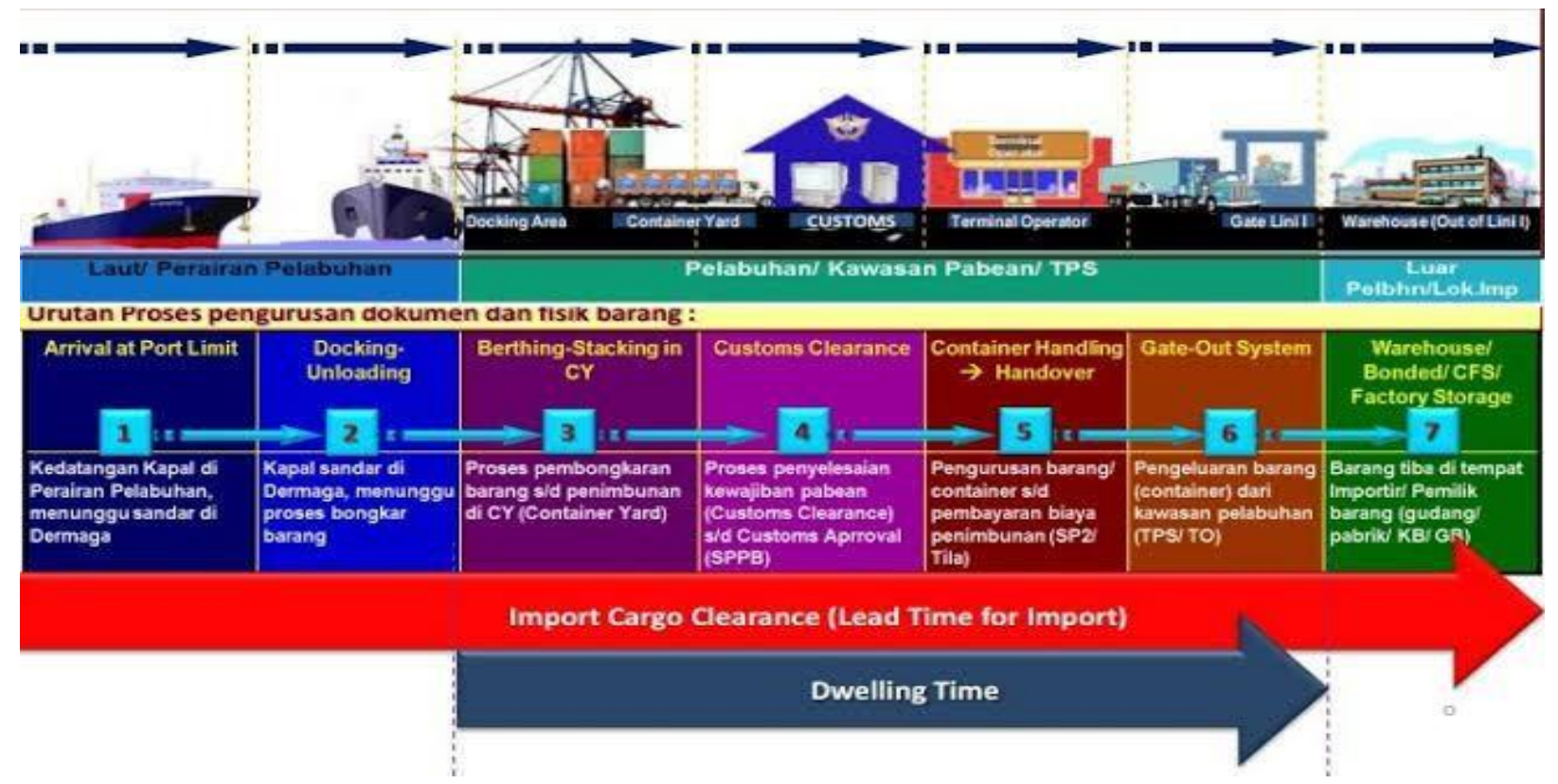

Figure 1. Logistic Flow at Harbor

Based on the image above, there are three activity zones in national logistic namely service zone at sea or port water area, service zone at port that includes customs area or Tempat Penimbunan Sementara (TPS), and service outside the port. Each zone has various activities and involves some parties: government sector as well as private sector.

\subsubsection{Logistic Activity Process at Sea Zone or Port Naval Area}

At port naval area, in addition to the ship entry approval, shipment company or the appointed sailing agent at least conducts ship harboring process at port naval area, ship guiding and/or tugging process to port, harboring and tying process at dock.
Various declarations have to be submitted by shipping company or agent such as Ship Arrival Declaration (Pemberitahuan Kedatangan Kapal PKK) accompanied by shipping document and sailors' document to the General Directorate of Naval Transportation, Inward Manifest Declaration (BC 1.1) to the General Directorate of Customs and Excise, Request for Ship Sanitation Checking to Harbor Health Agency, Declaration of Unloading and Loading Activity Plan to the Unloading and Loading Company, payment Non-Tax State Revenue to the General Directorate of Treasury, and Tugging Request to the Harbor Administrator Authority. Tugging is required for a ship with GT 500 gross or more weight. ${ }^{[8]}$

Although the majority of those declarations above mentioned can be submitted online already, the submission needs additional time and cost. The additional time and cost in service process at port naval area inflicts additional cost component paid in order to procure a good. This factor causes sale price 
to be higher and lose in competition with the similar products produced in countries with lower logistic cost.

\subsubsection{Logistic Activity at Port}

Activity process at port area is more complicated and normally needs longer time, higher cost and involves more stakeholders. The activity starts from unloading process that normally in the form of containers, to the clearance of goods from port. Service stage in this zone also serves as standard in measuring the good clearance speed at port that is normally referred to as dwelling time.

According to Manalystics (1976), in general terms, the container dwell time is the average time a container remains stacked on the terminal and during which it waits for some activity to occur. ${ }^{9}$ Dwelling time is basically the time needed, measured from the time goods are unloaded from ship or transportation mean up to the clearance of goods from port.

In order to be able to unload goods from ship, shipping company or sailing agent has to prepare some documents, among other container vessel identification advice (CVIA), edi baplie namely data containing information regarding container's position on ship, container special handling list, ship particular data, and general stowage (ship stowage image). ${ }^{[9]}$ For the CVIA submitted by sailing company, the harbor administrator, in this case container terminal operator, prepares berthing plan,
Estimate Time Berthing (ETB), Crane Working Program (CWP), availability of unloading and loading equipment, and others.

Containers that are unloaded from the ship will be placed in a Tempat Penimbunan Sementara (TPS) or other similar place to a TPS. Placement at TPS is intended to wait for the clearance process at Customs and Excise. The speed of the clearance process at Customs and Excise depends on the readiness of complementary customs documents, the profile of the importer and the type of commodity being imported.

However, for certain types of goods, which are included in the category of restricted goods, licensing documents from the relevant agencies must be fulfilled. Fulfillment of permits from relevant agencies is the part that takes the longest time in the clearance process. Many importers have not completed the import requirements from the relevant agencies when the goods arrive at the port. This results in the process of releasing goods from the port to be long.

The international community is very concerned about the speed of releasing goods from the port, which is usually called dwelling time. The government has made various efforts to strengthening dwelling time since the last few years. From the data presented online through the INSW page, ${ }^{[10]}$ it is known that the dwelling times of major Indonesian ports are as follows:

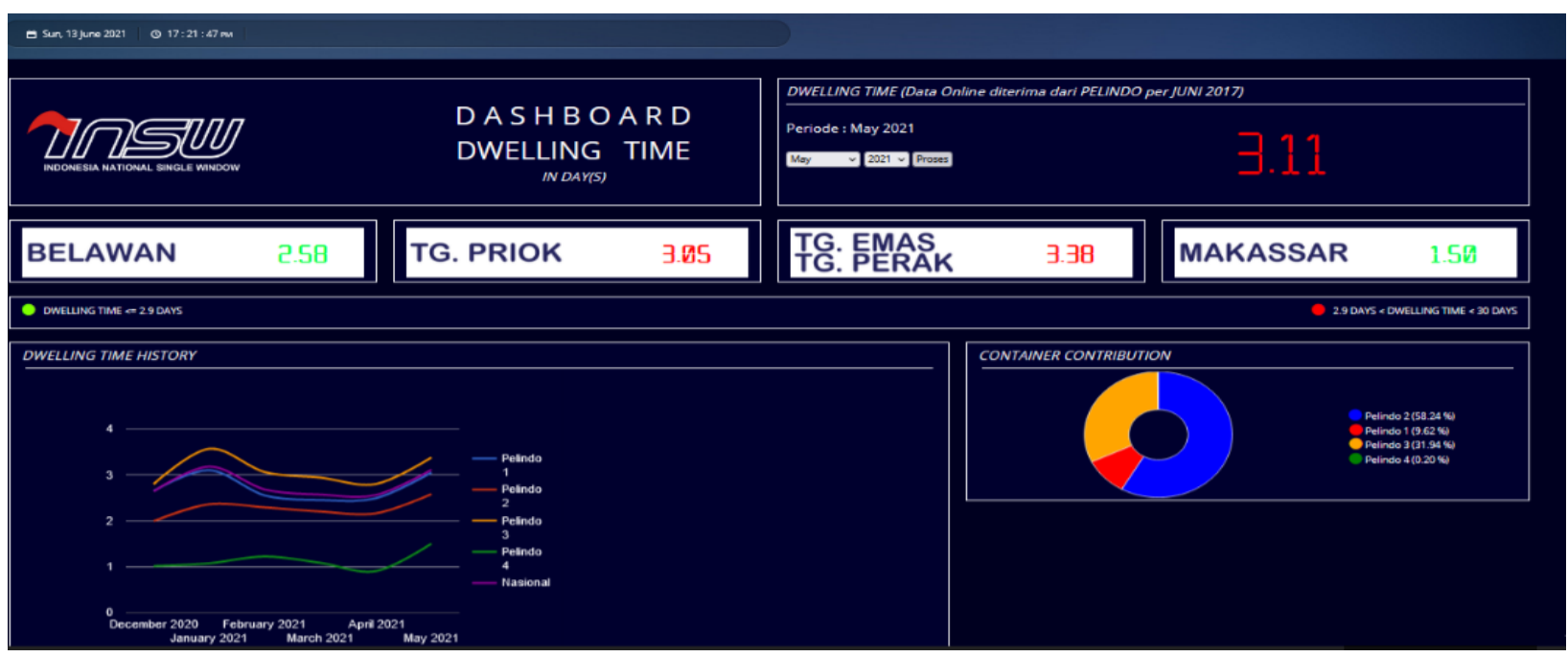

Figure 2. Dwelling Time of Major Indonesian Ports in May 2021

The dwelling time data for May 2021 is slightly better than the dwelling time data for May 2020. In May 2020 the dwelling time for Belawan is 2.81 days, Tanjung Priok is 3.35, Tanjung Emas and Tanjung Perak are 3.18 and Makassar is 1.35. These improvements have not been able to lift Indonesia's logistics performance.
Complexity of services at ports, the availability of loading and unloading facilities, import and/or export licensing processes, access to logistics services, duplication and repetition of documents, and the absence of a logistics platform from upstream to downstream are some of the causes of logistics inefficiency in Indonesia. 


\subsubsection{Process of Activities Outside the Port}

The process of releasing goods at the port begins when the importer has received a Letter of Approval for the Release of Goods (SPPB) from Customs and Excise. Based on this SPPB, the importer pays the fee to the Port Management Agency. The cost of the delivery note which consists of the cost of Stacking Containers plus the cost of Lift on Container and after that you just get a Container Delivery Letter (SP2). ${ }^{[1]}$ SP2 or commonly known as Tila is what the trailer driver brings to the port to pick up the container to be delivered according to the importer's request.

Constraints that are usually faced at this stage are related to the lift on container process which sometimes has to look for a fork lift operator or reach stacker or crane and wait in line for lift on. The most complex thing after gate out is transportation congestion after exiting the port, especially at Tanjung Priok port as the largest sea port in Indonesia. Transportation travel time is much longer due to congestion that often occurs between ports and industrial centers. This causes high costs in the logistics process.

\subsection{National Logistics Strengtheningment Priority To Strengthening Indonesia's Competitiveness}

From data released by the World Bank (2018), Indonesia's Logistics Performance Index (LPI) reached 3.15, which was the highest in the last 10 years. This achievement is a combination of customs, infrastructure, international shipping, logistics competence, tracking and tracing, and timeliness. However, the Secretary General of the Ministry of Transportation, Djoko Sasono, also revealed that the increase in LPI has not been matched by a decrease in logistics costs. Indonesia's national logistics costs are still quite high. National logistics costs for the last 3 years are still stuck at $23.5 \%$ of GDP. ${ }^{[12]}$

Currently, each agency has made strengtheningments to logistics services according to their respective duties and authorities. However, efforts to strengthening national logistics need to be carried out in a more comprehensive and modern way. Not only partial repairs carried out by each activity actor at the port, both government agencies and private parties. Based on the current condition of the port and based on the studies conducted by the author, the priority for improving national logistics is related to regulation, digitization and infrastructure.

\subsubsection{Regulatory Strengtheningments}

There is a legal adage which states that the law is always behind the development of society. Many regulations must be updated to adapt to current economic developments. Satjipto Rahardjo introduced the term progressive law. Progressive law enforcement is carrying out the law not just black and white words from regulations (according to the letter), but according to the spirit and deeper meaning (to very meaning) of the law or law. Law enforcement is not only intellectual intelligence, but also spiritual intelligence. In other words, law enforcement is carried out with determination, empathy, dedication, commitment to the suffering of the nation and accompanied by the courage to find other ways than what is usually done.

In the logistics sector, there are still many rules that must be synchronized and updated. For example, regulations that still require stakeholders to submit documents in hardcopy, service promises are still long, there are still duplication of document submissions such as notification of ship arrivals that must be submitted to port authorities, Customs and Excise, quarantine and Port Business Entities, etc.

\subsubsection{Service Digitization}

The port is one of the entrances for people, goods and services to a country. Various activities are found in the port as previously described. Both activities carried out at ports are carried out by government agencies and private parties. There are at least 11 (eleven) government agencies that carry out service and supervision activities at ports. Likewise private parties who carry out commercial activities at ports such as Port Business Entities, shipping companies, banks, freight forwarders, loading and unloading companies, stockpiling and warehousing companies, land transportation companies and so on.

Currently, several port services have been carried out digitally using various platforms. The Directorate General of Sea Transportation displays an application system under the name INAPORTNET, the Directorate General of Customs and Excise with the CEISA Application, Health Quarantine, the Directorate General of Disease Prevention and Control uses the SINKARKES application, the Directorate General of Budget uses the SIMPONI application in payment of Non-Tax State Revenue (PNBP), still available Indonesia National Single Window (INSW) application managed by the National Single Window Institute.

In addition to the applications managed by these government agencies, there are also many applications that are managed by the private sector in the context of their services to their respective stakeholders. The use of this application is very useful and has succeeded in reducing service time to stakeholders. However, there are still many services that are still done manually.

The priority for strengtheningment is to build a portal that unifies all existing information systems, be it a private government logistics platform or a private 
logistics platform. All services are digitized and are in one platform. This has actually been pioneered in an application called the National Logistic Ecosystem (NLE). However, it needs acceleration in the completion and use of this application. This application is also expected to accommodate single submissions in logistics services, so that repetition problems can be resolved.

\subsubsection{Infrastructure Strengtheningment}

Infrastructure is one of the weak points that the international world spotlights on Indonesia. Starting from infrastructure at the port to infrastructure outside the port. It is necessary to modernize the equipment of various ports in Indonesia such as loading and unloading equipment, lift on lift off, gate in gate out, docking place, stockpile etc.

Besides, the strengtheningment of infrastructure outside the port is also very urgent. In efficiency due to damaged roads, congestion that occurs at the port gates is very high. The road from the port to the industrial centers must be rearranged and repaired. Building a railway network from ports to industrial centers is also an alternative for logistics strengtheningments that can reduce high costs.

\section{CONCLUSION}

1. The Indonesian government has made efforts to strengthening national logistics, but the results of the Logistics Performance Index survey conducted by the world bank have not shown significant results. The condition of logistics services in port waters, services at ports and services after leaving the port are still not integrated, many agencies are carried out with their respective platforms, many documents are submitted repeatedly, infrastructure facilities at the port are not yet modern making the process take longer, infrastructure outside port is not good, resulting in congestion of the port route to industrial centers.

2. To increase competitiveness in international trade, Indonesia must strengthening the overall national logistics conditions. Priority strengtheningments are made related to regulatory strengtheningments, digitization and integration between service platforms, both government and private, as well as strengtheningments to infrastructure in ports and infrastructure outside ports.

\section{AUTHORS' CONTRIBUTIONS}

Before the results of this study were written, there had been several studies related to national logistics. Previous research was conducted partially according to a particular topic. The government has also campaigned for the development of the National Logistics Ecosystem. Through the results of this study, the author wants to add to the treasures of scientific writings that can be used by further researchers and can also be used by policy makers in developing the concept of the National Logistics Ecosystem.

\section{ACKNOWLEDGMENTS}

On this occasion, I would like to thank my supervisors, translators, classmates at the law faculty of Universitas Sumatera Utara, family, and those who helped in the completion of this paper. Hopefully this article is useful to add insight related to national logistics.

\section{REFERENCES}

[1] https://www.viva.co.id/berita/bisnis/1022627biaya-logistik-ri-masih-25-30-persen-dari-nilaibarang

[2] Russel, Roberta.S dan Bernard W Taylor, Operations Management, Fourth Edition, Pearson Education International, 2009, h. 406

[3] https://nle.kemenkeu.go.id/portal/\#/

[4] https://nle.kemenkeu.go.id/portal/\#/

[5] Mochtar Kusumaatmaja, Konsep-konsep Hukum Dalam Pembangunan, Edisi I, PT.Alumni, Bandung, 2002, hal.v

[6] https://supplychainindonesia.com/alur-logistikpeti-kemas-bagian-1-dari-2-tulisan/

[7] Ling Li , Pearson International Edition Operation management, Eighth Edition 2007, Penerbit Pearson Prentice

[8] Pasal 28 Peraturan Menteri Perhubungan Nomor : PM-57 Tahun 2015 tentang Pemanduaan dan penundaan Kapal

[9] Tedy Herdian, S.Kom, M.M., Alur Logistik Peti Kemas, di muat di https://supplychainindonesia.com tanggal 19 November 2018

[10] https://apps3.insw.go.id/dashboard_dtinsw.php

[11] Imeyla Eknis Lestari, Mochammad Al Musadieq, MBA., Supriono S.Sos, MAB., Analisis Kendala Dan Upaya Pelabuhan Dalam Mengurangi Lamanya Dwelling Time Seerta Dampaknya Terhadap Volume EKspor Dan Impor (Studi Pada PT. Terminal Peti Kemas Surabaya), Jurnal Administrasi Bisnis (JAB)| Vol. 51 No. 1 Oktober 2017

[12] https://balitbanghub.dephub.go.id/berita/pemod erasi-efisiensi-biaya-logistik-nasional-dipelabuhan-dengan-determinasi-it. 